\title{
MORPHOMETRIC STUDY OF NECK OF DRY ADULT FEMORA
}

\section{Mrunal Muley ${ }^{* 1}$, Pritha Bhuiyan ${ }^{2}$.}

\author{
${ }^{*}$ Assistant Professor, Department of Anatomy, GMC Aurangabad, Maharashtra, India. \\ ${ }^{2}$ Professor and Head, Department of Anatomy, Seth G.S. Medical College, Mumbai, Maharashtra, \\ India.
}

\section{ABSTRACT}

Introduction: Fractures of proximal femur including neck and trochanters are quite common. The implants used for surgical treatment of femoral fractures are designed according to the dimensions of proximal femur which are designed according to dimensions suitable for western population. The current study aims to construct data of morphometry of neck of femur in Indian population.

Materials and Methods: The study was conducted on 150 dry adult femora from the bone collection of the Department of Anatomy of G. S. Medical College Mumbai. Width of neck of femur and length of neck of femur on anterior and posterior aspect were measured.

Observation and Results: Mean width of neck of femur $(29.38 \pm 2.50 \mathrm{~mm}$ on right side and $28.86 \pm 3.47 \mathrm{~mm}$ on left side); mean length of neck of femur on anterior aspect; ( $34.96 \pm 7.18 \mathrm{~mm}$ on right side and $33.42 \pm 4.12 \mathrm{~mm}$ ) and mean length of neck of femur on posterior aspect ( $39.55 \pm 5.81 \mathrm{~mm}$ on right side and $40.00 \pm 4.60 \mathrm{~mm}$ on left side) were calculated.

Conclusion: Indian dimensions of neck of femur are different as compared to those of other population. The current morphometric study of neck of femur will be very useful for designing implants used for surgical correction of femoral neck fracture which will suit Indian population.

KEY WORDS: Adult femora, Neck and trochanters, Proximal femur, Femoral neck fracture.

Address for Correspondence: Dr. Mrunal Muley, Assistant Professor, Department of Anatomy, Government Medical College, Aurangabad, Maharashtra. India Mob. 9987708985,

E-Mail: mrunal.137@gmail.com

\begin{tabular}{|c|c|c|}
\hline \multicolumn{3}{|c|}{ Access this Article online } \\
\hline \multirow{2}{*}{$\begin{array}{l}\text { Quick Response code } \\
\text { DOI: } 10.16965 / \text { ijar.2017.321 }\end{array}$} & \multicolumn{2}{|c|}{$\begin{array}{l}\text { Web site: International Journal of Anatomy and Research } \\
\qquad \text { ISSN 2321-4287 } \\
\text { www.ijmhr.org/ijar.htm }\end{array}$} \\
\hline & $\begin{array}{l}\text { Received: } 23 \text { June } 2017 \\
\text { Peer Review: } 23 \text { June } 2017 \\
\text { Revised: } 29 \text { June } 2017\end{array}$ & $\begin{array}{l}\text { Accepted: } 03 \text { Aug } 2017 \\
\text { Published (O): } 31 \text { Aug } 2017 \\
\text { Published (P): } 31 \text { Aug } 2017\end{array}$ \\
\hline
\end{tabular}

\section{INTRODUCTION}

Femur is the longest and strongest bone of the human body. Its length is associated with a straiding gait, its strength with the weight and muscular forces it is required to withstand [1]. Neck of the femur in humans is an important functional modification after man attained erect posture.

Fractures of proximal femur including neck and trochanters are quite common. Internal fixation of these fractures with implants ismandatory for early mobilization and rehabilitation of the patients. The implants used for surgical treatment of femoral fractures including dynamic hip screws, cancellous screws, blade and plates are designed according to the dimensions of proximal femur. These implants are exclusively designed according to the western dimensions. The usage of these oversized implants adversely affects the functional end result of surgery [2].

Most of the Indian orthopaedic surgeons have currently felt the need for the modification in 
implant sizes suitable for Indian population. Moreover not many studies are performed on morphometric analysis of proximal femur in Indian population. This study was thus carried out to define the geometry of proximal femur in Indian population.

\section{MATERIALS AND METHODS}

The study was conducted on dry adult femora. The femora were obtained from the bones collection of the Department of Anatomy of G. S. Medical College Mumbai. From the total collection of femora, 150 undamaged femora were selected for the study. The femora were of undetermined gender and age.

Materials used for measurement of different parameters are as below:

1. Digital vernier caliper

2. Measuring scale

3. Non-elastic cotton thread

The following parameters were recorded

Width of neck of femur: Width of the neck is measured at its narrowest part in supero-inferior direction by using digital vernier calliper. (Fig. 1)

Fig.1: Image illustrating measurement of width of femur.

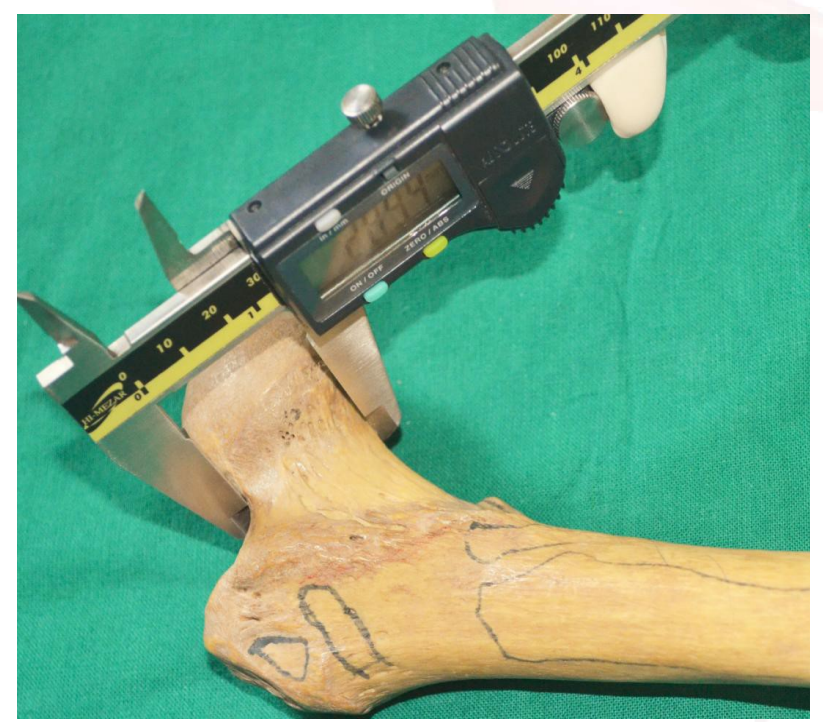

Length of neck of femur on anterior aspect:It is the distance between the base of the head and intertrochanteric line. It was measured along the line that is perpendicular to intertrochanteric line which divides anterior part of neck into two equal (upper and lower) halves. It was measured with the help of non- elastic cotton thread. (Fig. 2)
Fig. 2: Image illustrating measurement of length of neck of femur on anterior aspect of femur.

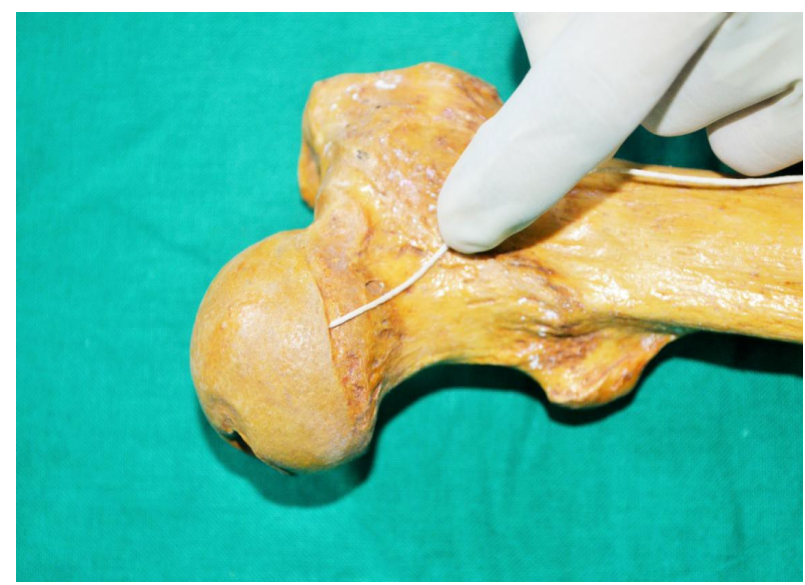

Length of neck of femur on posterior aspect:It is the distance between the base of the head and intertrochanteric crest. It was measured along the line that is perpendicular to intertrochanteric crest which divides posterior part of neck into two equal (upper and lower) halves. It was measured with the help of non-elastic cotton thread. (Fig.3)

Fig.3: Image illustrating measurement of length of neck of femur on posterior aspect of femur.

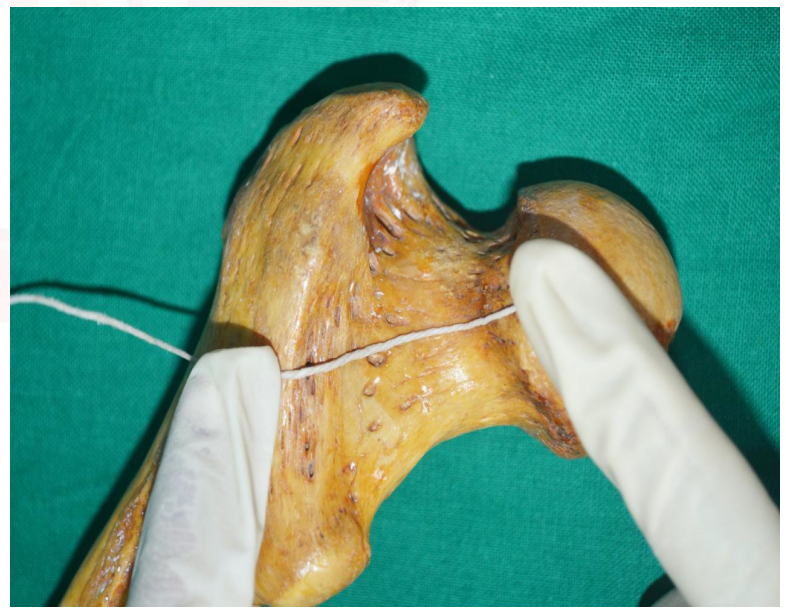

\section{OBSERVATION AND RESULTS}

Width of Neck of Femur: The width of neck of femur on right side ranged from 22.68 - 34.64 $\mathrm{mm}$ with a mean of $29.38 \pm 2.50 \mathrm{~mm}$.

The width of neck of femur on left side ranged from $20.30-35.06 \mathrm{~mm}$ with a mean of $28.86 \pm$ $3.47 \mathrm{~mm}$

Table 1: Width of Neck of Femur.

\begin{tabular}{|c|c|c|c|c|c|}
\hline Side & $\begin{array}{c}\text { Number } \\
\text { of bones }\end{array}$ & $\begin{array}{c}\text { Minimum } \\
(\mathrm{mm})\end{array}$ & $\begin{array}{c}\text { Maximum } \\
(\mathrm{mm})\end{array}$ & $\begin{array}{c}\text { Mean } \\
(\mathrm{mm})\end{array}$ & $\begin{array}{c}\text { Standard } \\
\text { Deviation }\end{array}$ \\
\hline Right & 78 & 22.68 & 34.64 & 29.38 & 2.5 \\
\hline Left & 72 & 20.3 & 35.06 & 28.86 & 3.47 \\
\hline
\end{tabular}


Length of Neck of Femur on Anterior Aspect: The mean length of neck of femur on anterior aspect; on right side was estimated to be 34.96 $\pm 7.18 \mathrm{~mm}$ with a range between $24.00-57.00$ $\mathrm{mm}$.

The mean length of neck of femur on anterior aspect; on left side was estimated to be $33.42 \pm$ $4.12 \mathrm{~mm}$ with a range between $25.00-45.00$ $\mathrm{mm}$.

Table 2: Length of Neck of Femur on Anterior Aspect.

\begin{tabular}{|c|c|c|c|c|c|}
\hline Side & $\begin{array}{c}\text { Number of } \\
\text { bones }\end{array}$ & $\begin{array}{c}\text { Minimum } \\
(\mathrm{mm})\end{array}$ & $\begin{array}{c}\text { Maximum } \\
(\mathrm{mm})\end{array}$ & $\begin{array}{c}\text { Mean } \\
(\mathrm{mm})\end{array}$ & $\begin{array}{c}\text { Standard } \\
\text { Deviation }\end{array}$ \\
\hline Right & 78 & 24 & 57 & 34.96 & 7.18 \\
\hline Left & 72 & 25 & 45 & 33.42 & 4.12 \\
\hline
\end{tabular}

Length of neck of femur on posterior aspect: The mean length of neck of femur on posterior aspect; on right side was estimated to be 39.55 \pm 5.81 with a range between $28.00-55.00 \mathrm{~mm}$.

The mean length of neck of femur on posterior aspect; on left side was estimated to be $40.00 \pm$ 4.60 with a range between $30.00-52.00 \mathrm{~mm}$.

Table 3: Length of neck of femur on posterior aspect.

\begin{tabular}{|c|c|c|c|c|c|}
\hline Side & $\begin{array}{c}\text { Number of } \\
\text { bones }\end{array}$ & $\begin{array}{c}\text { Minimum } \\
(\mathrm{mm})\end{array}$ & $\begin{array}{c}\text { Maximum } \\
(\mathrm{mm})\end{array}$ & $\begin{array}{c}\text { Mean } \\
(\mathrm{mm})\end{array}$ & $\begin{array}{c}\text { Standard } \\
\text { Deviation }\end{array}$ \\
\hline Right & 78 & 28 & 55 & 39.55 & 5.81 \\
\hline Left & 72 & 30 & 52 & 40 & 4.6 \\
\hline
\end{tabular}

\section{DISCUSSION}

In the past, several quantitative anatomical studies of adult femora have been carried out in different countries. Many authors have studied the various parameters of femur using different materials such as dry bones, cadaveric specimens, plain radiographs, Computed Tomography (CT) scans and Magnetic Resonance Imaging (MRI) scans.

Width of neck of femur: The value of width of neck of femur in present study was less than that in most of the previous studies. However, the observations were in line with the studies by Baharuddin MY et al [6].

Length of neck of femur on anterior aspect: The length of neck of femur on anterior aspect in present study was slightly more than that observed by Edurardo Branco et al [5] and D Ravichandran et al [2] and less than that observed by Osorio $\mathrm{H}$ et al [8]. Observations by Subhash Gujar en et al [9] were however, comparable with present study.

Table 4: Comparison of width of neck of femur with previous studies.

\begin{tabular}{|c|c|c|c|c|}
\hline Study & Year & Country & $\begin{array}{c}\text { Material for } \\
\text { study }\end{array}$ & Mean (in mm) \\
\hline Taner Ziylan et al [3] & 2002 & Turkey & Dry bones & $\begin{array}{c}\text { Left: } 30.60 \\
\text { Right: } 30.70\end{array}$ \\
\hline AK Mishra et Al 2009 [4] & 2009 & Nepal & Cadavers & 30.52 \\
\hline Edurardo Branco et al 2010 [5] & 2010 & Brazil & Radiographs & $\begin{array}{c}\text { Left: } 31.00 \\
\text { Right: } 30.96\end{array}$ \\
\hline Baharuddin MY et al 2011 [6] & 2011 & Malaysia & CT scans & $\begin{array}{c}\text { Males: } 28.90 \\
\text { Females: } 26.00\end{array}$ \\
\hline D Ravichandran et al 2011 [2] & 2011 & India & Dry bones & 30.99 \\
\hline Md. Shahajahan chowdhary et al 2012 [7] & 2012 & Bangladesh & Dry bones & $\begin{array}{c}\text { Males: } 46.90 \\
\text { Females: } 46.70\end{array}$ \\
\hline Present study & & India & Dry bones & $\begin{array}{c}\text { Left: } 28.86 \\
\text { Right: } 29.86\end{array}$ \\
\hline
\end{tabular}

Table 5: Comparison of length of neck of femur on anterior aspect with previous studies.

\begin{tabular}{|c|c|c|c|c|}
\hline Study & Year & Country & $\begin{array}{c}\text { Material for } \\
\text { study }\end{array}$ & Mean (in mm) \\
\hline Edurardo Branco et al 2010 [5] & 2010 & Brazil & Radiographs & $\begin{array}{c}\text { Left: } 30.50 \\
\text { Right: } 30.10\end{array}$ \\
\hline D Ravichandran et al 2011 [2] & 2011 & India & Dry bones & 30.09 \\
\hline Osorio H et al 2012 [8] & 2012 & Chile & Dry bones & 35.9 \\
\hline Subhash Gujar et al 2013 [9] & 2013 & India & Dry bones & $\begin{array}{c}\text { Left: } 34.20 \\
\text { Right: } 34.50\end{array}$ \\
\hline Present study & & India & Dry bones & $\begin{array}{c}\text { Left: } 33.42 \\
\text { Right: } 34.96\end{array}$ \\
\hline
\end{tabular}

Length of neck of femur on posterior aspect: The mean value of length of neck on posterior aspect was more than that in study by $D$ Ravichandran et al [2].

D Ravichandran et al [2] found that the length of neck on posterior aspect to be between 20.00 $-48.00 \mathrm{~mm}$ as compared to $28.00-55.00 \mathrm{~mm}$ in the present study.

Table 6: Comparison of length of neck of femur on posterior aspect with previous studies.

\begin{tabular}{|c|c|c|c|c|}
\hline Study & Year & Country & $\begin{array}{c}\text { Material for } \\
\text { study }\end{array}$ & Mean (in mm) \\
\hline D Ravichandran et al 2011 [2] & 2011 & India & Dry bones & 33.68 \\
\hline \multicolumn{2}{|c|}{ Present study } & India & Dry bones & $\begin{array}{c}\text { Left: } 40.00 \\
\text { Right: } 39.55\end{array}$ \\
\hline
\end{tabular}

The difference in the observation by $D$ Ravichanran et aland current study is due to different methods used for measuring length of femur on anterior and posterior aspect. $D$ Ravichandran et al used vernier calliper for measuring above mentioned parameters whereas in present study cotton thread was used for the same. 


\section{CONCLUSION}

The morphometric landmarks of neck 150 adult femora were evaluated. The various parameters of neck of femur were measured. The measurements were statistically analysed and results presented. These metric parameters were compared with those available in the literature and their clinical implications were discussed.

The current study has constructed a data for proximal end of the femur in Indian population. The results of the present study shows that the Indian dimensions of neck of femur is different as compared to other population. It will be very useful for designing implants used for surgical correction of femoral neck fracture which will suit Indian population; for radiological practice in identifying pathology of bone, determining age and in reconstruction surgeries. It could hence be stated that this study will prove to be useful along the broad spectrum of medical science such as anatomy, radiology, orthopaedics and forensic medicine.

\section{Conflicts of Interests: None}

\section{REFERENCES}

[1]. Standring S, Vishy Mahadevan. Pelvic girdle and lower limb. Gray's Anatomy: The Anatomical Basis of Clinical Practice. 40th ed. Edinburgh: Elsevier Churchill Livingstone; 2008;1360-1365

[2]. D. Ravichandran, N Muthukumaravel, R. Jaikumar, Das $\mathrm{H}$, Rajendran M. Pxoximal femoral geometry in Indians and its clinical applications.J.Anat. Soc.India 2011;60(1):6-12
[3]. Taner Z, Khalil A M. An Analysis of Anatolian Human Femur Anthropometry. Turk J Med Sci. 2002;32:231235.

[4]. Mishra AK, Chalise P, singh RP and Shah RK. The proximal femur- a second look at rational of implant designNepal Med Coll J 2009;11(4):278-280.

[5]. De Sousa E, Fernandes R. M. P., Mathias M B, Rodrigues MR, Ambram A. J. \& Babinski M. A Morphometric study of the proximal femur extremity in Brazilians. Int. J. Morphol., 2010;28(3):835-840.

[6]. BaharuddinA M Y, Kadir R A, Zulkifly A H, Saat A, Aziz A A \& Lee M. Morphology study of the proximal femur in Malay population. Int. J. Morphol., 2011;29(4):1321-1325.

[7]. Md. Chowdhary S, Naushaba H, Chowdhury M, KhanLF, Gulsan Ara J. Morphometric study of fully ossified head and neck diameter of the human left femur J. Dhaka National Med. Coll. Hos. 2012;18 (02):9-13.

[8]. Osorio H; Schorwer K.; Coronado C; Delgado J, \& Aravena P. Proximal femoral epiphysis anatomy in Chilean population. Orthopedic and forensic aspects. Int. J. Morphol. 2012;30(1):258-262.

[9]. Gujar S, Vikani S, Parmar J, Bondre K.V. A correlation between femoral neck shaft angle to femoral neck length. IJBAR;2013:04(05):295-298.

How to cite this article:

Mrunal Muley, Pritha Bhuiyan. MORPHOMETRIC STUDY OF NECK

OF DRY ADULT FEMORA. Int J Anat Res 2017;5(3.2):4317-4320.

DOI: 10.16965/ijar.2017.321 